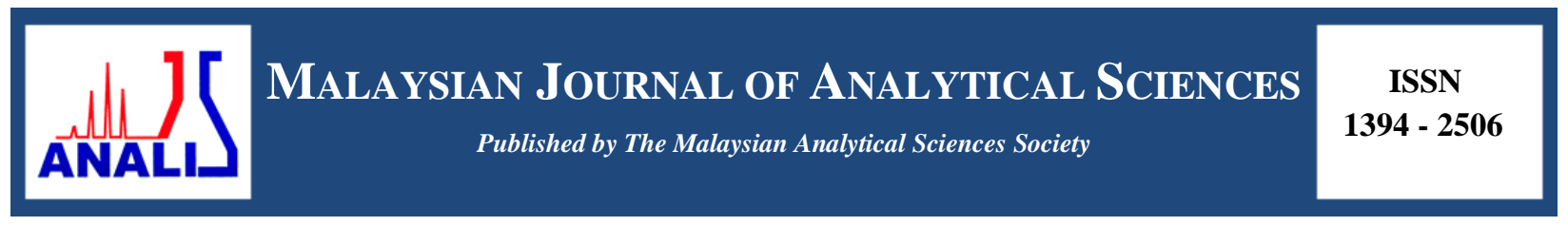

\title{
SEPARATION OF L-ARGININE AND L-CITRULLINE IN RED AND YELLOW CRIMSON WATERMELON (Citrullus lanatus) JUICES EXTRACT USING HPLC GRADIENT MODE
}

\author{
(Pemisahan L-Arginina dan L-Sitrulina dalam Ekstrak Jus Tembikai (Citrullus lanatus) Merah \\ dan Kuning Menggunakan Mod Cerun KCPT)
}

\author{
Rasdin Ridwan ${ }^{1}$, Hairil Rashmizal Abdul Razak ${ }^{2}$, Mohd Ilham Adenan ${ }^{3,4}$, Wan Mazlina Md Saad ${ }^{1 *}$ \\ ${ }^{1}$ Centre of Medical Laboratory Technology, Faculty of Health Sciences, \\ Universiti Teknologi MARA Selangor, Puncak Alam Campus, 42300 Bandar Puncak Alam, Selangor, Malaysia \\ ${ }^{2}$ Centre for Diagnostic Nuclear Imaging, Faculty of Medicine \& Health Sciences, \\ Universiti Putra Malaysia, 43400 Serdang, Selangor, Malaysia \\ ${ }^{3}$ Faculty of Applied Sciences, \\ Universiti Teknologi MARA, 40450 Shah Alam, Selangor, Malaysia \\ ${ }^{4}$ Atta-ur-Rahman Institute for Natural Product Discovery, Aras 9, Bangunan FF3, \\ Universiti Teknologi MARA Selangor, Puncak Alam Campus, 42300 Bandar Puncak Alam, Selangor, Malaysia \\ *Corresponding author: wanmaz755@salam.edu.uitm.my
}

Received: 29 August 2017; Accepted: 28 August 2018

\begin{abstract}
Watermelon (Citrullus lanatus) is a nutritious fruit that has attracted scientific interest due to its phytonutrient content including carotenoids and amino acids. Watermelon juice is the richest known source of amino acids including L-arginine and L-citrulline. For a complete separation of amino acids in watermelon juices, a gradient mode of reverse phase high performance liquid chromatography (RP-HPLC) with UV detection was utilised owing to its supremacy over isocratic mode. This present study was aimed at achieving good separation of chromatography profiles and baseline between L-arginine and L-citrulline in red and yellow crimson watermelon juice extract. The edible parts of watermelons were juiced, stored at $-80{ }^{\circ} \mathrm{C}$ and freeze dried to obtain dried juice powder. Samples were analysed by gradient mode of RP-HPLC using $0.1 \%$ orthophosphoric acid in water (v/v) and acetonitrile as mobile phase $\mathrm{A}$ and $\mathrm{B}$. The chromatograph separation was performed using Gemini $\mathrm{C}_{18}$ column at a flow rate of $1.0 \mathrm{~mL} / \mathrm{min}$, maintained temperature at $25{ }^{\circ} \mathrm{C}$ while detection was made at four different wavelengths; $195 \mathrm{~nm}, 200 \mathrm{~nm}$, $207 \mathrm{~nm}$ and $210 \mathrm{~nm}$ with total analysis time of $35 \mathrm{~min}$. Excellent chromatographic separation was achieved at conditions of gradient elution $(0 \% \mathrm{~B}-95 \% \mathrm{~B}, 0-18$ minutes and $95 \% \mathrm{~B}, 18-23$ minutes, $95 \% \mathrm{~B}-0 \% \mathrm{~B}, 23-25$ minutes, 0\% $\mathrm{B}, 25-35$ minutes) with baseline between L-arginine and L-citrulline in both watermelon juice extracts. The gradient mode used in this RP-HPLC successfully achieved efficient separation of chromatographic profile for amino acids, L-arginine and L-citrulline in the red and yellow crimson watermelon juice extracts.
\end{abstract}

Keywords: separation, L-arginine, L-citrulline, watermelon, juices extract

Abstrak
Tembikai (Citrullus lanatus) adalah buah yang berkhasiat yang menarik perhatian saintifik kerana kandungan fitonutriennya
seperti karotenoid dan asid amino. Jus tembikai mempunyai asid amino yang tinggi termasuk L-arginina dan L-sitrulina. Untuk
pemisahan lengkap asid amino dalam ekstrak jus tembikai, mod cerun fasa terbalik kromatografi cecair prestasi tinggi (FT-
KCPT) dengan pengesanan UV dijalankan kerana kehebatannya berbanding mod isokratik. Kajian ini bertujuan mencapai
pemisahan yang baik bagi profil kromatografi dan garis dasar antara L-arginina dan L-sitrulina dalam ekstrak jus tembikai
merah dan tembikai kuning. Isi buah tembikai ditapis, disimpan di - $80^{\circ} \mathrm{C}$ dan diletakkan dalam proses pengeringan-beku untuk 


\section{Rasdin et al: SEPARATION OF L-ARGININE AND L-CITRULLINE IN RED AND YELLOW CRIMSON WATERMELON (Citrullus lanatus) JUICES EXTRACT USING GRADIENT MODE}

mendapatkan serbuk jus kering. Sampel dianalisis menggunakan mod cerun FT-KCPT dengan $0.1 \%$ asid ortofosforik dicairkan dalam air (v/v) dan asetonitril sebagai fasa bergerak A dan B. Pemisahan kromatografi dilakukan dengan menggunakan turus Gemini $\mathrm{C}_{18}$ pada kadar aliran $1.0 \mathrm{~mL} / \mathrm{min}$, suhu yang dikekalkan pada $25{ }^{\circ} \mathrm{C}$ dan pengesanan dibuat pada empat panjang gelombang yang berbeza; $195 \mathrm{~nm}, 200 \mathrm{~nm}, 207 \mathrm{~nm}$ dan $210 \mathrm{~nm}$ dengan 35 minit masa analisis keseluruhan. Pemisahan kromatografi yang cemerlang dicapai dengan keadaan elusi kecerunan $(0 \%$ B - 95\% B, 0-18 minit dan 95\% B, 18-23 minit, 95\% B-0\% B, 23-25 minit, 0\% B, 25-35 minit) dengan garis dasar antara L-arginina dan L-sitrulina dalam kedua-dua ekstrak jus tembikai. Mod cerun dalam FT-KCPT ini berjaya mencapai pemisahan profil kromatografi yang efisien untuk asid amino, Larginina dan L-sitrulina dalam ekstrak jus tembikai merah dan kuning.

Kata kunci: pemisahan, L-arginina, L-sitrulina, tembikai, ekstrak jus

\section{Introduction}

Watermelon or scientifically known as Citrullus lanatus is categorised as a member of Cucurbitaceae family that incorporates several other important fruits such as muskmelon, cucumber, pumpkin, bottle ground and winter melon [1]. Citrullus lanatus is a vine-like flowering fruit mainly found worldwide in tropical and subtropical climates especially in Africa, Asia and Mediterranean [2]. Watermelon contains abundant carotenoid content that includes lycopene, $\beta$-carotene, lutein and neoxanthin, which are responsible for different watermelon flesh colours [3]. Red fleshed watermelon contains rich source of lycopene as the major carotenoid and secondarily, $\beta$-carotene [3]. Yellow crimson, a yellow fleshed watermelon contains major carotenoid known as neoxanthin that plays specific role in protection against photooxidative stress [3]. Recent report from previous studies have shown that both red and yellow crimson watermelon juices contain high concentration of amino acids especially L-arginine and Lcitrulline $[4,5]$. These amino acids are crucial in nitric oxide production for improving cardiovascular health, immune boosting, and sexual health benefits [6].

Amino acid profiling has been reported in numerous literatures using reverse phase high performance liquid chromatography (RP-HPLC) method following isocratic or gradient elution [7-10]. RP-HPLC has become the dominant mode for analytical analysis due to its excellent resolving power and versatile nature [11]. Previously, most RP-HPLC gradient methods for amino acid analysis including L-citrulline and L-arginine are performed along with pre- and post-column amino acid derivatisation using O-phthalaldehyde (OPA), but these methods require expensive equipments and tedious sample preparation [12]. Several derivatisation techniques using OPA in amino acid analysis have been conducted by isocratic HPLC, but the outcome was hampered by poor separation and overlapping of derivative peaks [13]. Recently, Jayaprakasha et al. [14] has successfully determined L-citrulline using isocratic elution method in reverse phase column, Gemini $\mathrm{C}_{18}$ with limitation for separation for single amino acid, L-citrulline. Therefore, the present study was aimed to achieve good separation of chromatography profiles and baseline between L-arginine and L-citrulline in two types of watermelon juices extract, the red and yellow crimson watermelons by gradient mode of RP-HPLC method.

\section{Chemicals and reagents}

\section{Materials and Methods}

Pure standards of L-arginine and L-citrulline were purchased from Sigma-Aldrich (St. Louis, MO). Phosphoric acid, $\geq 85 \%$ (Sigma-Aldrich) and HPLC grade deionised filtered water were used to prepare the mobile phase A. Acetonitrile, LiChrosolv gradient grade, was obtained from Merck (Darmstadt, Germany) as mobile phase B. All solutions were filtered by Durapore PVDF membrane, $0.45 \mu \mathrm{m}$ (Merck, Germany) and degassed prior to the HPLC experiments. All chemicals and reagents used were of HPLC grade.

\section{Sample and standard preparation}

Locally harvested red and yellow crimson watermelons (Citrullus lanatus) were obtained from Selangor Fruit Valley, Rawang. Both watermelons were cleaned with filtered tap water, peeled to obtain the fleshes with the remaining seeds removed. Watermelons fleshes were chopped into small pieces. The fleshes were then processed with a commercial juice extractor (Panasonic, MY) that automatically separates the pulp and the juices. The juices were stored at $-80^{\circ} \mathrm{C}$ and freeze-dried using Benchtop Freeze Dry System (Labconco, Kansas City, MO) to obtain dried juices powder. The freeze-dried juices were stored at $-80{ }^{\circ} \mathrm{C}$ until further analysis. An amount 5 mg of freezedried juices was dissolved in $1 \mathrm{~mL}$ deionised filtered water to yield $5 \mathrm{mg} / \mathrm{mL}$ of juice extract concentration. 
Meanwhile, pure standard of L-arginine and L-citrulline were dissolved in deionised water to obtain $1 \mathrm{mg} / \mathrm{mL}$ stock solution. Fresh working standard and juices extracts were prepared daily and all solutions were filtered by nylon syringe filter $(0.45 \mu \mathrm{m})$.

\section{Instrumentation}

Thermo Scientific ${ }^{\mathrm{TM}}$ UltiMate 3000 HPLC system was utilised for analysis. The system was equipped with an ultra-high pressure pump, column compartment, auto sampler, on-line degasser and diode array detector (DAD). The chromatographic profiles and integrated data were recorded using Chromeleon software version 7. The chromatographic separation was achieved using reverse phase column, Gemini $\mathrm{C}_{18}, 110 \AA, 3 \mu \mathrm{m}$ partial size, $250 \mathrm{x}$ $4.6 \mathrm{~mm}$ (Phenomenex, USA) in gradient mode.

\section{RP-HPLC analysis}

Chromatographic profiling of red and yellow watermelon juices extracts was performed on Thermo Scientific ${ }^{\mathrm{TM}}$ UltiMate 3000 HPLC system with diode array detector (DAD) and column temperature maintained at $25^{\circ} \mathrm{C}$. The Chromeleon chromatographic software was used for data collection and processing. A $20 \mu \mathrm{L}$ of standard and juice extracts were automatically injected by the auto sampler. Elution was conducted using mobile phase A $(0.1 \%$ orthophosphoric acid in water $(\mathrm{v} / \mathrm{v}))$ and mobile phase B (100\% acetonitrile) with a linear gradient elution programme (Table 1) at a flow rate of $1.0 \mathrm{~mL} / \mathrm{min}$. The following gradient was applied: $0 \% \mathrm{~B}-95 \% \mathrm{~B}, 0-18$ minutes and $95 \% \mathrm{~B}, 18-23$ minutes, $95 \% \mathrm{~B}-0 \% \mathrm{~B}, 23-25$ minutes, $0 \% \mathrm{~B}, 25-35$ minutes with total analysis time of 35 minutes. Detection was monitored at four different wavelengths: $195 \mathrm{~nm}, 200 \mathrm{~nm}, 207 \mathrm{~nm}$ and $210 \mathrm{~nm}$. Prior to analysis, the system was purged to remove bubbles from the line tubes. The column was conditioned for at least 30 minutes until flat baseline was achieved. In each chromatographic run, the column was flushed with $95 \%$ acetonitrile followed by 10 minutes at solvent composition for the next injection.

Table 1. Linear gradient elution

\begin{tabular}{lcc}
\hline $\begin{array}{l}\text { Time } \\
\text { (minutes) }\end{array}$ & $\begin{array}{c}\text { \% A } \\
\left(\mathbf{0 . 1 \%} \mathbf{H}_{\mathbf{3}} \mathbf{P O}_{\mathbf{4}}\right)\end{array}$ & $\begin{array}{c}\text { \% B } \\
(\mathbf{A C N})\end{array}$ \\
\hline 0 & 100 & 0 \\
18 & 5 & 95 \\
23 & 5 & 95 \\
25 & 100 & 0 \\
35 & 100 & 0 \\
\hline
\end{tabular}

\section{Results and Discussion}

The present study has successfully achieved excellent chromatography profiles for separation two types of juice extract, red and yellow crimson watermelons, using gradient mode RP-HPLC. The linear gradient profile developed as shown in Figure 1 resulted in lowest baseline drift and provide excellent separation of amino acid, L-arginine and L-citrulline. The present result showed improvement from previous study conducted by Rao and Bitla [15] that demonstrated incomplete separation of L-arginine and L-citrulline without baseline resolve using gradient mode RP-HPLC. Gradient elution was confirmed to be performed in this analysis as the ratio in retention time, $\Delta \mathrm{t}$, between the first, ta, and the last peak, $t z$, of compounds in linear gradient was $>0.25$. This gradient programme was selected to achieve maximum separation and sensitivity. The linear gradient phase was performed by changing acetonitrile composition from the starting condition of $0 \%$ acetonitrile to $95 \%$ acetonitrile from 0 to 18 min. This phase is called as gradient time (tg) in which the solvent composition is changed to elute compounds of different polarity. The presence of acetonitrile in the starting solvent for the gradient elution is necessary to ensure the elution of both amino acids, L-arginine and L-citrulline, within a reasonable time. Acetonitrile was preferred as organic solvent due to lower viscosities and low UV cut off compared to methanol that often causes a higher baseline noise with electrochemical detection [16]. This can be confirmed by Abdullah et al. [17] study that stated the use of acetonitrile resulted in sharper peak shape and better resolution in a shorter analysis time than methanol. 


\section{Rasdin et al: SEPARATION OF L-ARGININE AND L-CITRULLINE IN RED AND YELLOW CRIMSON WATERMELON (Citrullus lanatus) JUICES EXTRACT USING GRADIENT MODE}

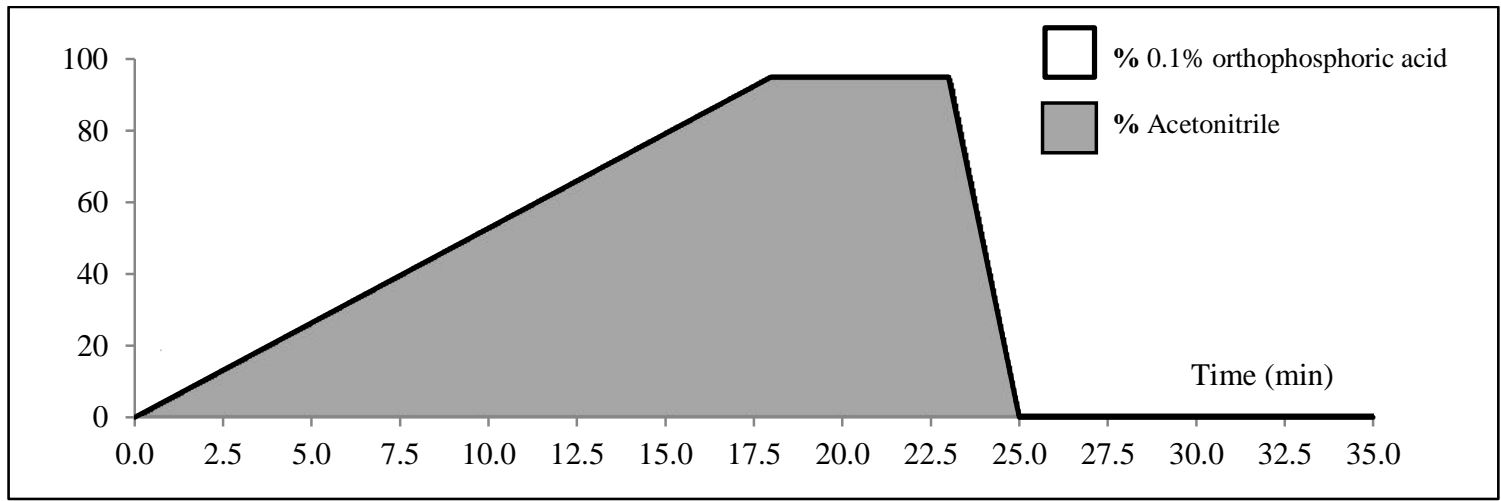

Figure 1. The linear gradient elution from 0 to 18 minutes; the graph represents the percentage of solvent $\mathrm{A}(0.1 \%$ phosphoric acid) and solvent B (acetonitrile

The chromatography separations of mixed standard, red and yellow crimson watermelon juice extracts at linear gradient phase were shown in Figure 2. The chromatographic profile of standard solution presented in Figure 2a showed that the standard mixture of L-arginine and L-citrulline was perfectly separated without any derivatisation. L-arginine was eluted first at retention time of $4.350 \mathrm{~min}$ followed by L-citrulline at $5.320 \mathrm{~min}$. Excellent separation on chromatography profile in standard solution was achieved although additional minor peaks were observed, which might be due to reagent purity. The chromatography profiles of red and yellow crimson watermelon juice extracts showed well-separated peaks of 11 major compounds that were eluted including L-arginine and L-citrulline (Figures $2 \mathrm{~b}$ and $2 \mathrm{c}$ ). L-arginine and L-citrulline exhibited excellent baseline separation, good resolution and peak symmetry with increasing steepness under the gradient elution conditions. The finding was supported by Markowski et al. [18] and Mao et al. [19] that demonstrated successfully separation of L-arginine and L-citrulline with good baseline and resolution under gradient elution. Interestingly, only small minor additional peaks were observed on the chromatograph results even though simple extraction step was performed without sample clean-up. This simple extraction method provides convenient sample preparation and reduces instrumental requirements, hence less equipped laboratories are required to carry out this analysis [20]. 


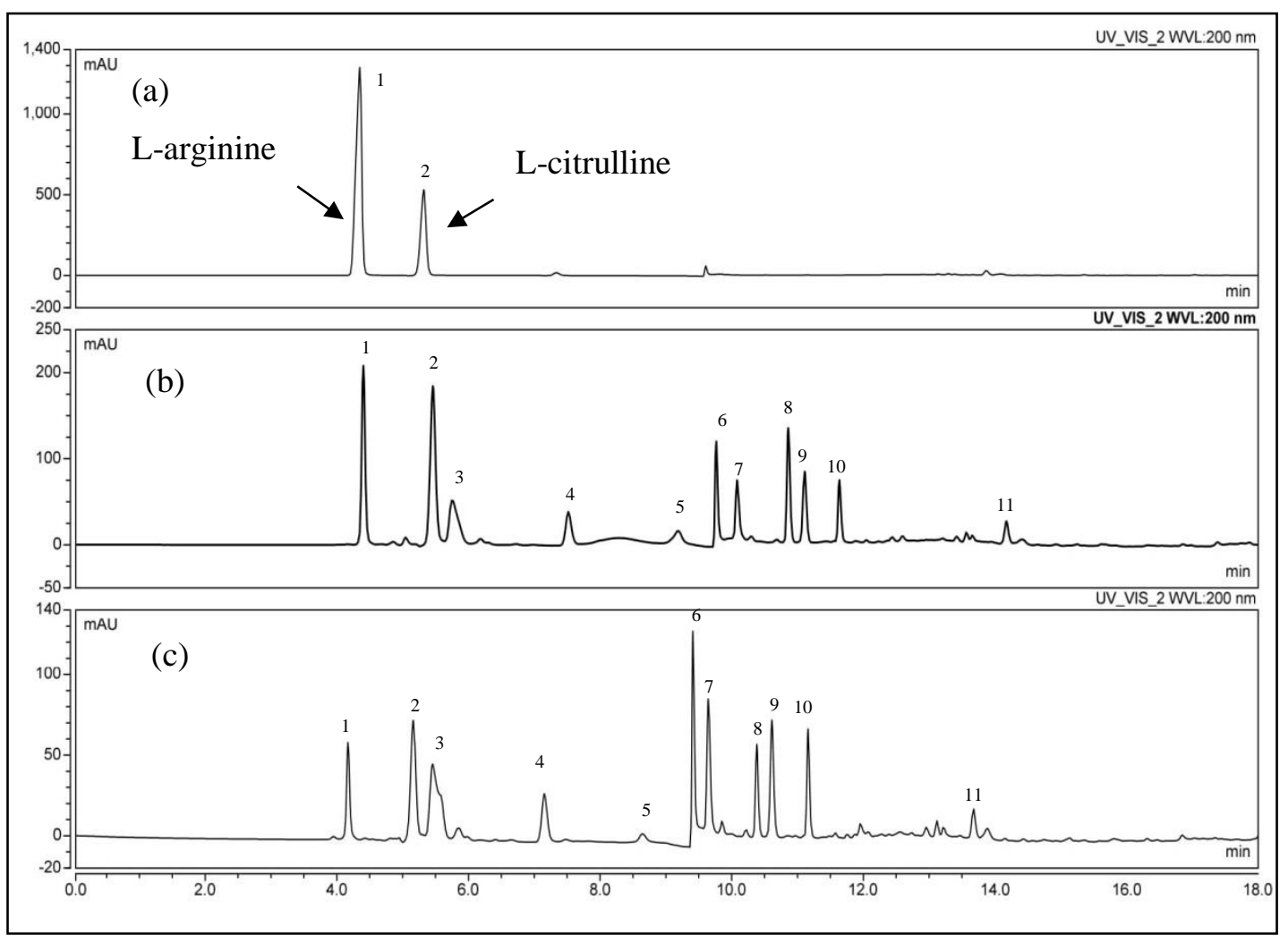

Figure 2. Comparison of RP-HPLC chromatographic profiles of (a) standard mixture solution (L-arginine, 1 $\mathrm{mg} / \mathrm{mL}$ and L-citrulline, $1 \mathrm{mg} / \mathrm{mL}$ ), (b) red watermelon juice extract (c) yellow crimson watermelon juice extract; $20 \mu \mathrm{L}$ of mixed standard or samples were injected into the HPLC system; mobile phase flow of $1.000 \mathrm{~mL} / \mathrm{min}$; linear gradient (ACN: $0 \%$ to $95 \%$ in 18 minutes); UV/Vis detector wavelength of $200 \mathrm{~nm}$; column oven maintained at $25{ }^{\circ} \mathrm{C}$.

The effects of UV wavelengths on detection of L-arginine and L-citrulline were also determined within the range of $195 \mathrm{~nm}$ to $210 \mathrm{~nm}$. The selection was done based on the previous literatures conducted by Ridwan et al. [5], Jayaprakasha et al. [14] and Sadji et al. [21] for underivatisation amino acid analysis. Comparison on chromatography profiles of red and yellow crimson watermelon juice extracts at four different wavelengths detection of $195 \mathrm{~nm}, 200 \mathrm{~nm}, 207 \mathrm{~nm}$ and $210 \mathrm{~nm}$ are showed in Figure 3 and 4, respectively. Detection of compounds at $200 \mathrm{~nm}$ yielded most stable and low baseline noise between peak of compounds in the chromatography profiles. Highest signal intensity of compounds was achieved at $195 \mathrm{~nm}$ but the chromatography baseline was less stable while the detection of signal intensity was decreased at $207 \mathrm{~nm}$ and $210 \mathrm{~nm}$. This present finding is in agreement with Agrafiotou et al. [22] that showed high sensitivity detection of underivatised amino acids mixture at wavelength $200 \mathrm{~nm}$ compared to $190 \mathrm{~nm}$ and $210 \mathrm{~nm}$. The lower wavelengths ranging from $195 \mathrm{~nm}$ to $210 \mathrm{~nm}$ were chosen in this study since most amino acids with appropriate functional group of carboxylic group (-COOH) including L-arginine and L-citrulline can only be detected at low UV wavelengths [5, 22]. Hesse and Weller [20] supported the notion that lower UV range provides high sensitivity, but interference of solvents, buffers, and other additives is often prohibitive. Thus, it is crucial to used proper mobile phases as there is only limited number of buffer components and electrolyte additives that can function optimally at low wavelengths. The employed mobile phase of $0.1 \%$ orthophosphoric acid and acetonitrile produced reproducible separation of Larginine and L-citrulline in red and yellow crimson watermelon juice extracts at $200 \mathrm{~nm}$. 


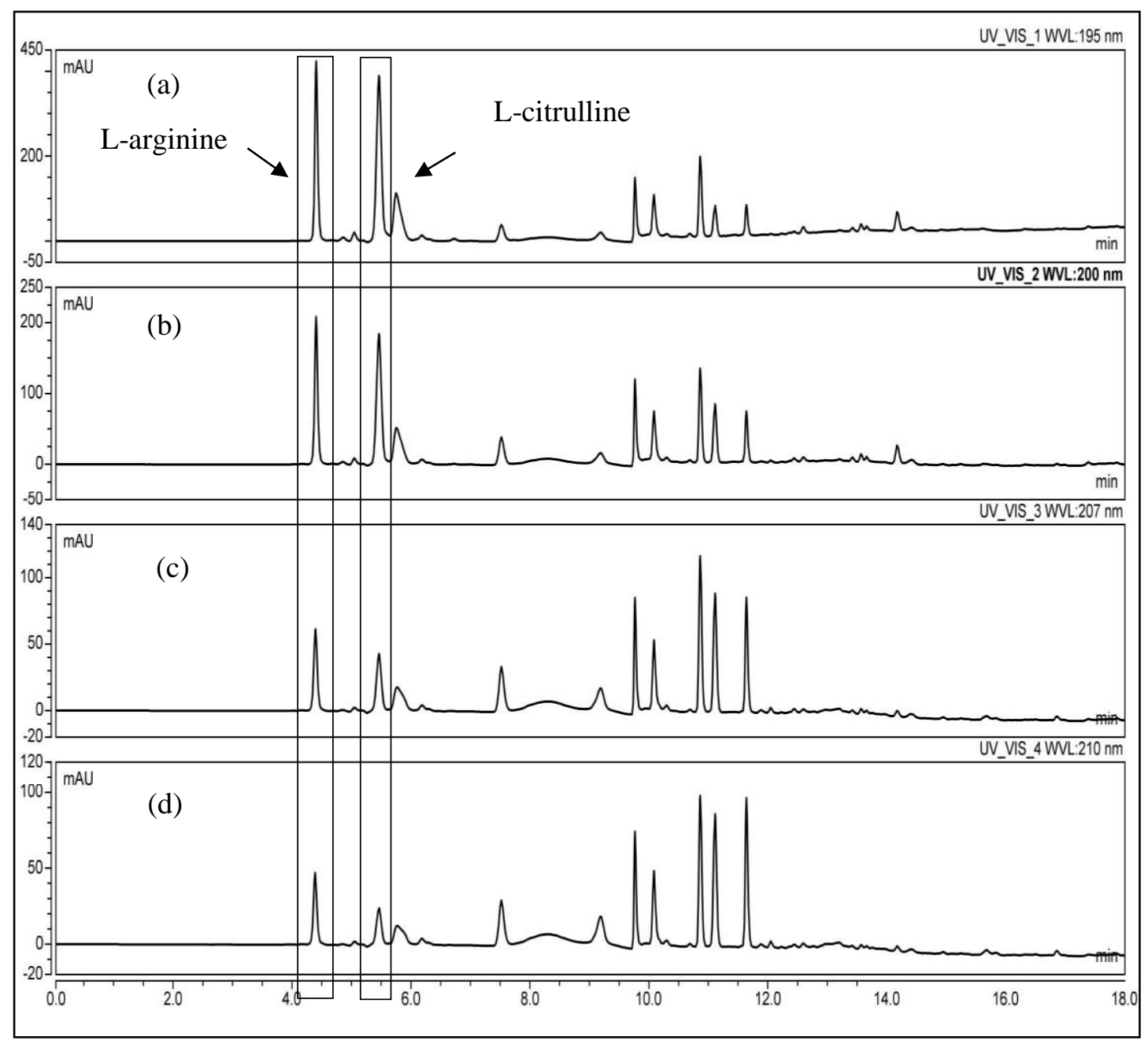

Figure 3. Comparison of chromatographic profiles obtained by gradient mode RP-HPLC in different wavelengths for red watermelon juice extract; (a) $195 \mathrm{~nm}$ (b) $200 \mathrm{~nm}$ (c) $207 \mathrm{~nm}$ (d) $210 \mathrm{~nm} ; 20 \mu \mathrm{L}$ of samples were injected into the HPLC system; mobile phase flow of $1.000 \mathrm{~mL} / \mathrm{min}$; linear gradient (ACN: $0 \%$ to $95 \%$ in 18 minutes); column oven was maintained at $25^{\circ} \mathrm{C}$. 


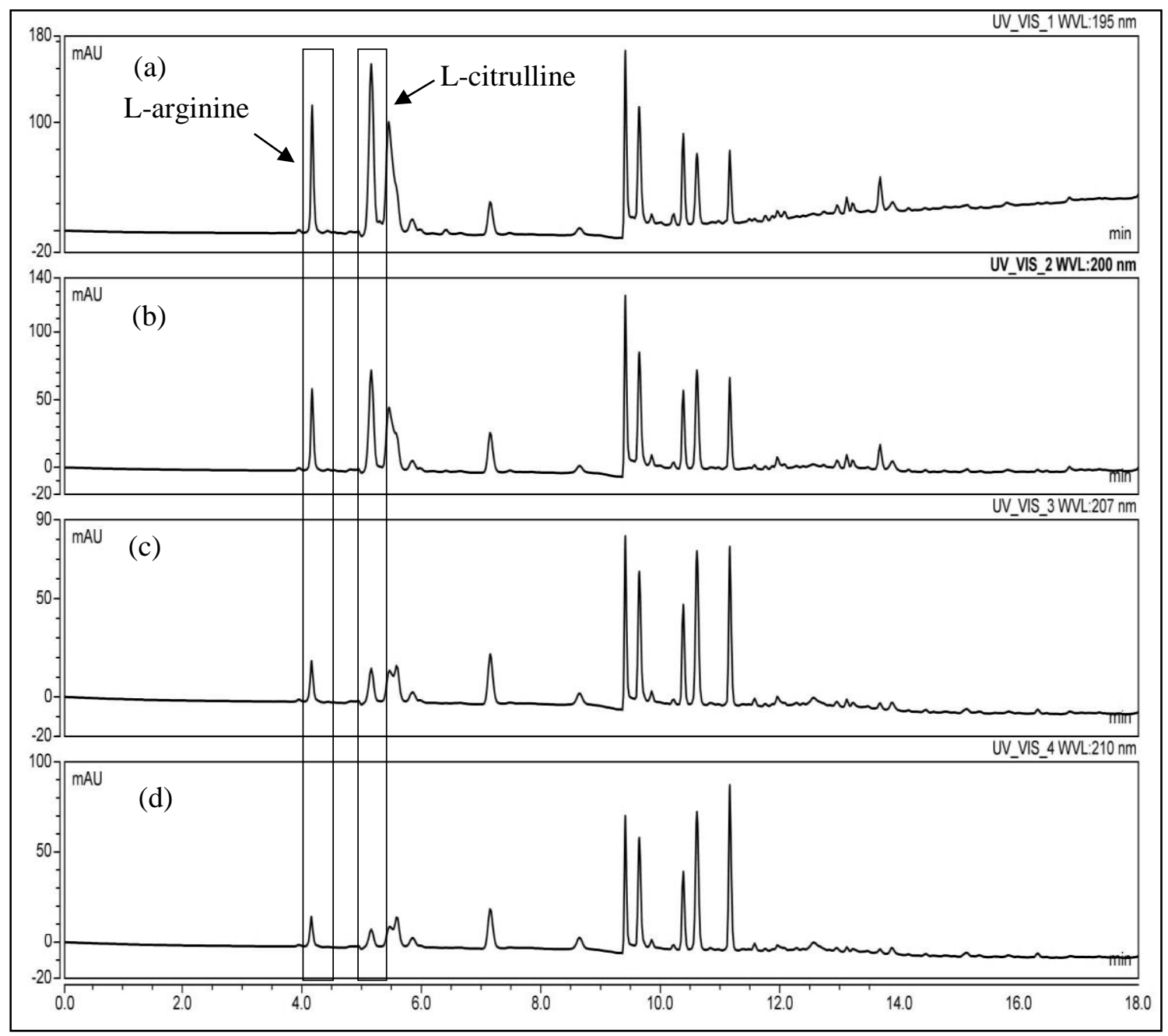

Figure 4. Comparison of chromatographic profiles obtained by gradient mode RP-HPLC in different wavelengths for yellow crimson watermelon juice extract; (a) $195 \mathrm{~nm}$ (b) $200 \mathrm{~nm}$ (c) $207 \mathrm{~nm}$ (d) $210 \mathrm{~nm} ; 20 \mu \mathrm{L}$ of samples were injected into the HPLC system; mobile phase flow of $1.000 \mathrm{~mL} / \mathrm{min}$; linear gradient (ACN: $0 \%$ to $95 \%$ in 18 minutes); column oven was maintained at $25{ }^{\circ} \mathrm{C}$.

\section{Conclusion}

The gradient mode of RP-HPLC has successfully achieved efficient separation of chromatographic profile in linear gradient phase and baseline between L-arginine and L-citrulline in red and yellow watermelon juice extracts using Gemini $\mathrm{C}_{18}$ with $0.1 \%$ orthophosphoric acid in water (v/v) and acetonitrile as mobile phase at $200 \mathrm{~nm}$. L-arginine and L-citrulline were excellently separated. The method is simple with minimum samples preparation without any derivatisation that could potentially solve the problems in derivatisation techniques for amino acid analysis. However, further study is warranted for a complete analysis of amino acid profiles using the gradient mode RPHPLC and to quantify its content in local watermelon. It is also necessary to explore the roles of these bioactive constituents in watermelon as nutritional intervention for maintaining a healthy lifestyle.

\section{Acknowledgement}

The authors gratefully acknowledge financial support by the Ministry of Higher Education, Malaysia through Fundamental Research Grant Scheme (FRGS/1/2016/WAB01/UITM/02/3) and Institute of Research 
Management and Innovation (IRMI), Universiti Teknologi MARA. The authors also would like to acknowledge Atta-ur-Rahman Institute (AuRIns), Centre of Medical Laboratory Technology, and Centre of Postgraduate Study of Faculty of Health Sciences, Universiti Teknologi MARA (UiTM) Selangor, Puncak Alam Campus for providing facilities throughout this study.

\section{References}

1. Mohammad, M. K. A., Mohamed, M. I., Zakaria, A. M., Abdul Razak, H. R. and Md Saad, W. M. (2014). Watermelon (Citrullus lanatus (Thunb.) Matsum. and Nakai) juice modulates oxidative damage induced by low dose X-ray in mice, BioMed Research International, 2014 :1-6.

2. Levi, A., Thomas, C.E., Keinath, A.P. and Wehner T.C. (2001). Genetic diversity among watermelon (Citrullus lanatus and Citrullus colocynthis) accessions. Genetic Resources and Crop Evolution, 48(6): 559-566.

3. Zhao, W., Lv, P. and Gu, H. (2013). Studies on carotenoids in watermelon flesh. Agricultural Sciences, 4(7): $13-20$.

4. Rimando, A. M. and Perkins-Veazie, P. M. (2005). Determination of citrulline in watermelon rind. Journal of Chromatography A, 1078(1-2): 196-200.

5. Ridwan, R., Abdul Razak, H. R., Adenan, M. I. and Md Saad, W. M. (2018). Development of isocratic RPHPLC method for separation and quantification of L-Citrulline and L-Arginine in watermelons. International Journal of Analytical Chemistry, 2018:1-9.

6. Egbuonu, A. C. C. (2015). Comparative assessment of some mineral, amino acid and vitamin compositions of watermelon (Citrullus lanatus) rind and seed. Asian Journal of Biochemistry, 10(5): 230-236.

7. Dimova, N. (2003). RP-HPLC analysis of amino acids with UV-detection. Comptes Rendus de l'Academie Bulgare des Sciences, 56(12): 12-75.

8. Shi, Z., Li, H., Li, Z., Hu, J. and Zhang, H. (2013). Pre-column derivatization RP-HPLC determination of amino acids in Asparagi radix before and after heating process. IERI Procedia, 5(2013): 351-356.

9. Sharma, V., Gulati, A. and Ravindranath, S. D. (2005). A simple and convenient method for analysis of tea biochemicals by reverse phase HPLC. Journal of Food Composition and Analysis, 18(6): 583-594.

10. Zafar, S., Naz, N., Nazir, S., Abbas, M. and Khan, A. M. (2014). Analysis of selected amino acids in different varieties of wheat available in Punjab, Pakistan. Chromatography Research International, 2014: 1-6.

11. Scott, R. P. W. (2003). Principles and practice of chromatography. Chrom-Ed Book Series, Library for Science Publishing, LCC, 1: pp $1-106$.

12. Adegoke, O. (2012). An overview of applications of pre-column derivatization reactions for the liquid chromatographic analysis of pharmaceuticals and other compounds. African Journal of Pure and Applied Chemistry, 6(12): 129-140.

13. Fish, W. W. (2012). A reliable methodology for quantitative extraction of fruit and vegetable physiological amino acids and their subsequent analysis with commonly available HPLC systems. Food and Nutrition Sciences, 3(6): 863-871.

14. Jayaprakasha, G. K., Chidambara Murthy, K. N. and Patil, B. S. (2011). Rapid HPLC-UV method for quantification of L-citrulline in watermelon and its potential role on smooth muscle relaxation markers. Food Chemistry, 127(1): 240-248.

15. Rao, P. V. L. N. S. and Bitla A. R. (2017). Simultaneous determination of arginine, citrulline, and asymmetric dimethylarginine in plasma by reverse-phase high-performance liquid chromatography. Journal of Laboratory Physicians. 9(4): 243-248.

16. Matysova, L., Zahalkova, O., Klovrzova, S., Sklubalova, Z., Solich, P. and Zahalka, L. (2015). Development of a gradient HPLC method for the simultaneous determination of sotalol and sorbate in oral liquid preparations using solid core stationary phase. Journal of Analytical Methods in Chemistry, 2015: 1-6.

17. Abdullah, N. F., Anifah, W. and Hussain, R. M. (2015). Optimised method for purification of allylpyrocatechol from Piper Betle L. ethanolic extract using HPLC and $\mathrm{H}^{1}$-NMR. Journal of Pharmaceutical Sciences and Research, 7(6): 292-301.

18. Markowski, P., Baranowska, I., and Baranowski, J. (2007). Simultaneous determination of L-arginine and 12 molecules participating in its metabolic cycle by gradient RP-HPLC method. Application to human urine samples. Analytica Chimica Acta, 605(2): 205-217. 
19. Mao, H. M., Wei, W., Xiong, W. J., Lu, Y., Chen, B. G. and Liu, Z. (2010). Simultaneous determination of Lcitrulline and L-arginine in plasma by high performance liquid chromatography. Clinical Biochemistry, 43(1314): 1141-1147.

20. Hesse, A. and Weller, M. G. (2016). Protein quantification by derivatization-free high-performance liquid chromatography of aromatic amino acids. Journal of Amino Acids, 2016: 1-8.

21. Sadji, M., Perkins-Veazie, P.M., Ndiaye, N.F., Traore, D., MA, G., Zongo, C., Traore, Y,, Sal, M.D. and Traore, A. (2015) Enhanced L-citrulline in parboiled paddy rice with watermelon (Citrullus lanatus) juice for preventing sarcopenia: A preliminary Study. African Journal of Food Science, 9(10): 508-513.

22. Agrafiotou, P., Sotiropoulos, S. and Pappa-Louisi, A. (2009). Direct RP-HPLC determination of underivatized amino acids with online dual UV absorbance, fluorescence, and multiple electrochemical detection. Journal of Separation Science, 32(7): 949-954. 